\title{
HUBUNGAN TINGKAT PARTISIPASI IBU DALAM KEGIATAN POSYANDU DENGAN STATUS GIZI ANAK BALITA (STUDI DI KELURAHAN CANGKIRAN KECAMATAN MIJEN KOTA SEMARANG)
}

\author{
Cahaya Asdhany, Apoina Kartini") \\ Program Studi Ilmu Gizi Fakultas Kedokteran Universitas Diponegoro \\ Jl.Dr.Sutomo No.14 Semarang, Telp (024) 8453708, Email : gizifk@undip.ac.id
}

\begin{abstract}
Background: Children under five years of age are included in group of nutrition's susceptible. They are on growth and development cycle which need a huge nutrient. The aim of this study is to understand the relationship between mother's participation levels in posyandu and nutritional status of children under five years of age.

Method: Study of analitical observation with cross sectional was used. Subject was a mother in Cangkiran, having children aged between 12-59 month. Subject was taken with proportional stratified random sampling technique. Mother's participation in posyandu was taken from health care staff's data, protein and energy intake were taken from food recall $3 \times 24$ hours, and nutritional status of children under five years of age was compared with Z-score of WHO 2005. Data was analyzed using Rank-Spearman and partial correlation used SPSS for Windows 19.0 software.

Result: Approximately 56,4\% of subjects have active participation's levels in posyandu. Much of the children under five years of age from those have 80,6\% good nutritional status (WAZ), 67,7\% normal (WHZ), 61,3\% normal (HAZ), and 61,3\% normal (BMIAZ). There is a relationship mother's participation levels in posyandu with nutritional status children under five years of age based on WAZ $\quad(p=0,030 ; r=0,651)$ but not for WHZ ( $p$ $=0,998 ; r=0,000), \operatorname{HAZ}(p=0,163 ; r=0,191)$, and BMIAZ $(p=0,689 ; r=-0,055)$. This realtionship is also controlled by sufficient levels of energy $\quad(p=0,047 ; r=0,639)$ and protein $(p=0,003 ; r=0,823)$. Conclusion: Increased participation levels of mother's in posyandu enhances nutritional status of children under five years of age (based on WAZ). This case is also influenced by sufficient levels of energy and protein.
\end{abstract}

Keyword: mother's participation levels; posyandu; nutritional status; children under five years of age

\section{ABSTRAK}

Latar Belakang: Anak balita termasuk kelompok rawan gizi, berada pada siklus pertumbuhan dan perkembangan yang memerlukan zat gizi jumlah besar. Penelitian ini bertujuan mengetahui hubungan tingkat partisipasi ibu dalam kegiatan posyandu dengan status gizi anak balita.

Metode: Jenis penelitian analitik observasional, desain cross sectional. Subjek adalah ibu di Cangkiran yang memiliki anak balita 12-59 bulan. Teknik pengambilan sampel proportional stratified random sampling. Partisipasi ibu di posyandu diperoleh dari data kader, asupan protein dan energi dari food recall $3 x 24$ jam, dan status gizi dibandingkan dengan skor Z WHO 2005. Analisis data dengan uji Rank-Spearman dan korelasi parsial menggunakan SPSS for Windows 19.0.

Hasil: Sebanyak 56,4\% subjek memiliki tingkat partisipasi aktif di posyandu. Sebagian besar anak balita dari ibu aktif memiliki status gizi baik, yakni status gizi baik 80,6\% (BB/U), normal 67,7\% (BB/TB), normal 61,3\% (TB/U), dan normal 61,3\% (IMT/U). Terdapat hubungan tingkat partisipasi ibu dalam kegiatan posyandu dengan status gizi anak balita berdasarkan BB/U $(p=0,030 ; r=0,651)$ tetapi tidak untuk BB/TB $(p=0,998 ; r=0,000), T B / U(p=$ $0,163 ; r=0,191)$, dan IMT/U $(p=0,689 ; r=-0,055)$. Hubungan ini juga dikontrol tingkat kecukupan energi $(p=$ $0,047 ; r=0,639)$ dan protein ( $p=0,003 ; r=0,823)$.

Simpulan: Semakin tinggi tingkat partisipasi ibu dalam kegiatan posyandu maka semakin baik pula status gizi anak balita berdasarkan BB/U. Hal ini turut dipengaruhi tingkat kecukupan energi dan protein.

Kata Kunci: tingkat partisipasi ibu; posyandu; status gizi; anak balita

\section{PENDAHULUAN}

Keberhasilan pembangunan bangsa ditentukan oleh ketersediaan Sumber Daya Manusia (SDM) berkualitas. Bukti empiris menunjukkan, hal ini sangat ditentukan oleh status gizi. ${ }^{1}$ Tingginya tingkat partisipasi ibu pada setiap kegiatan posyandu dapat berpengaruh pada peningkatan status gizi anak balita. Hal ini disebabkan posyandu diasumsikan sebagai salah satu pendekatan tepat untuk menurunkan angka kesakitan dan kematian serta dapat meningkatkan status gizi anak balita. ${ }^{2}$ Penimbangan di posyandu 
penting untuk memantau status gizi anak balita karena umumnya kekurangan gizi terjadi pada kelompok umur tersebut. Anak balita berada pada suatu siklus pertumbuhan dan perkembangan yang memerlukan zat-zat gizi dalam jumlah lebih besar daripada kelompok umur lain. ${ }^{3}$ Bukti anak balita merupakan kelompok rawan gizi, diperkuat dengan ditemukannya kasus gizi kurang sebesar 0,98\% dan gizi buruk sebesar $0,06 \%$ pada balita di Kota Semarang pada tahun $2011{ }^{4}$

Data Dinas Kesehatan Kota Semarang tentang penimbangan masyarakat di posyandu (cakupan D/S) selama tahun 2008 hingga 2011 menunjukkan hasil berfluktuatif. Cakupan D/S pada tahun 2008 mencapai $79,64 \%$ dan mengalami penurunan pada tahun 2009, yakni sebesar 76,46\%. ${ }^{5,6}$ Angka ini mengalami peningkatan pada tahun 2010 yaitu $87,3 \%$ dan di tahun 2011 kembali menurun, pencapaiannya hanya $77,21 \%{ }^{4,7}$ Target Standar Pelayanan Minimal (SPM) Provinsi Jawa Tengah tahun 2011 yaitu 80\%, sehingga data cakupan D/S balita Kota Semarang tahun 2011 masih dibawah target pencapaian. ${ }^{8}$ Hasil survei awal Dinas Kesehatan Kota Semarang, diketahui Puskesmas Mijen merupakan salah satu puskesmas dengan cakupan D/S terendah di Kota Semarang tahun 2011, yakni 70,71\%. ${ }^{4}$ Data laporan bulanan Puskesmas Mijen Januari hingga Desember 2011, menunjukan cakupan D/S di Kelurahan Cangkiran lebih rendah dibandingkan sembilan kelurahan lain yang berada di wilayah kerja Puskesmas Mijen, yakni $66,4 \% .^{9}$

Berdasarkan uraian masalah diatas maka peneliti tertarik untuk melakukan penelitian yang bertujuan mengetahui hubungan tingkat partisipasi ibu dalam kegiatan posyandu dengan status gizi anak balita yang dilakukan di Kelurahan Cangkiran Kecamatan Mijen Kota Semarang.

\section{METODE PENELITIAN}

Penelitian ini termasuk keilmuan gizi masyarakat, dilaksanakan Maret - Mei 2012. Jenis penelitian ini analitik observasional, dengan desain cross-sectional. Subjek penelitian diperoleh dengan proportional stratified random sampling. Berdasarkan perhitungan rumus korelatif, diperoleh sampel minimal 55 orang. Subjek penelitian yaitu anak balita dari ibu (responden) di 5 wilayah kerja posyandu Kelurahan Cangkiran yang memenuhi kriteria inklusi dan eksklusi. Kriteria inklusi antara lain anak balita tidak menderita penyakit infeksi terkait gizi dalam 2 minggu terakhir (batuk, pilek, demam, diare, campak, demam berdarah dengue/ DBD, malaria, infeksi saluran pernapasan atas/ ISPA, tuberkulosis/ TBC), ibu tidak menjadi kader posyandu, dan ibu bersedia mengisi informed consent. Kriteria eksklusi antara lain ibu pindah rumah, ibu mengundurkan diri, dan ibu dan/atau anak balita meninggal dunia.

Variabel bebas adalah tingkat partisipasi ibu dalam kegiatan posyandu. Data diperoleh dari kader posyandu (Mei 2011 - April 2012). Variabel kontrol adalah tingkat kecukupan energi (TKE) dan protein (TKP). TKE dan TKP merupakan rasio asupan energi dan protein dengan angka kecukupan energi (AKE) dan protein (AKP) individu, kemudian dikalikan $100,0 \%{ }^{10}$ Data asupan makan diperoleh melalui wawancara food recall 3x24 jam, diolah dengan Nutrisurvey 2007. Variabel terikat adalah status gizi anak balita berdasarkan Berat Badan menurut Usia $(\mathrm{BB} / \mathrm{U})$, Berat Badan menurut Tinggi Badan (BB/TB), Tinggi Badan menurut Usia $(\mathrm{TB} / \mathrm{U})$, dan Indeks Massa Tubuh menurut Usia (IMT/U). Data diolah menggunakan program WHO Antro 2005. Data berat badan diperoleh melalui penimbangan dengan dacin tanpa per atau timbangan digital kapasitas $200 \mathrm{~kg}$ dengan ketelitian $0,1 \mathrm{~kg}$. Data tinggi badan diperoleh melalui pengukuran dengan infantometer (usia $<2$ tahun/ belum mampu berdiri) atau mikrotoa (usia $\geq 2$ tahun/ sudah mampu berdiri). ${ }^{11}$

Tahap awal pengambilan data yaitu mewawancarai kader posyandu untuk memperoleh ibu yang membawa anak balitanya sendiri di setiap kegiatan posyandu. Kemudian dilakukan kunjungan rumah untuk mewawancarai ibu terkait kuesioner penapisan, penelitian, pengetahuan, dan food recall $3 \times 24$ jam. Selanjutnya dilakukan pengukuran antropometri pada anak balita secara terpusat.

Variabel penelitian dianalisis secara statistik menggunakan program Statistical Package for Social Science (SPSS) 19 for Windows. Analisis univariat digunakan untuk mendeskripsikan karakteristik subjek, responden, dan variabel penelitian. Variabel diuji kenormalan distribusi data dengan uji Kolmogorov-Smirnov $(\mathrm{n}>50)$. Analisis bivariat menggunakan korelasi RankSpearman karena tingkat partisipasi ibu dalam kegiatan posyandu sebagai satu-satunya variabel bebas tidak berdistribusi normal. Korelasi parsial digunakan untuk mengetahui hubungan tingkat partisipasi ibu dalam kegiatan posyandu dengan status gizi anak balita setelah dikontrol TKE dan TKP individu. 
HASIL PENELITIAN

I. Analisis Univariat

A. Karakteristik Subjek Penelitian
Tabel 1 mendeskripsikan faktor-faktor yang dapat mempengaruhi tingkat partisipasi ibu dalam kegiatan posyandu.

Tabel 1. Distribusi Frekuensi Karakteristik Subjek Penelitian

\begin{tabular}{|c|c|c|c|c|}
\hline \multirow{2}{*}{$\begin{array}{c}\text { Karakteristik } \\
\text { Subjek Penelitian }\end{array}$} & \multicolumn{2}{|c|}{$\begin{array}{l}\text { Partisipasi Ibu } \\
\text { Tidak Aktif }\end{array}$} & \multicolumn{2}{|c|}{$\begin{array}{c}\text { Partisipasi Ibu } \\
\text { Aktif }\end{array}$} \\
\hline & $\mathrm{n}$ & $\%$ & $\mathrm{n}$ & $\%$ \\
\hline \multicolumn{5}{|l|}{ Usia Anak Balita } \\
\hline $12-23$ Bulan & 7 & 29,2 & 9 & 29,0 \\
\hline $24-59$ Bulan & 17 & 70,8 & 22 & 71,0 \\
\hline \multicolumn{5}{|l|}{ Usia Ibu } \\
\hline Dewasa Muda (15 - < 32 Tahun) & 16 & 66,7 & 21 & 67,7 \\
\hline Dewasa Tua ( $\geq 32$ - 49 Tahun) & 8 & 33,3 & 10 & 32,3 \\
\hline \multicolumn{5}{|l|}{ Pendidikan Ibu } \\
\hline Tamat SD/ Sederajat & 5 & 20,8 & 2 & 6,5 \\
\hline Tamat SMP/ Sederajat & 7 & 29,2 & 7 & 22,6 \\
\hline Tamat SMA/ Sederajat & 8 & 33,3 & 15 & 48,4 \\
\hline Diploma/ Perguruan Tinggi & 4 & 16,7 & 7 & 22,6 \\
\hline \multicolumn{5}{|l|}{ Pengetahuan $\mathrm{Ibu}^{22}$} \\
\hline Kurang $(<60 \%$ jawaban benar) & 9 & 37,5 & 6 & 19,4 \\
\hline Sedang $(60-80 \%$ jawaban & 14 & 58,3 & 16 & 51,6 \\
\hline benar) & 1 & 4,2 & 9 & 29,0 \\
\hline \multicolumn{5}{|l|}{ Baik (> 80\% jawaban benar) } \\
\hline \multicolumn{5}{|l|}{ Status Pekerjaan Ibu } \\
\hline Tidak Bekerja & 20 & 83,3 & 26 & 83,9 \\
\hline Wiraswasta & 4 & 16,7 & 5 & 16,1 \\
\hline \multicolumn{5}{|l|}{ Jumlah Balita dalam Keluarga } \\
\hline 1 Balita & 20 & 83,3 & 22 & 71,0 \\
\hline$>1$ Balita & 4 & 16,7 & 9 & 29,0 \\
\hline \multicolumn{5}{|l|}{ Pendapatan Keluarga } \\
\hline Rendah $(\leq \operatorname{Rp} 939.756,00)$ & 9 & 37,5 & 6 & 19,4 \\
\hline Tinggi (>Rp 939.756,00) & 15 & 62,5 & 25 & 80,6 \\
\hline \multicolumn{5}{|l|}{ Kelengkapan Sarana Posyandu } \\
\hline Lengkap & 24 & 100,0 & 31 & 100,0 \\
\hline Tidak Lengkap & 0 & 0 & 0 & 0 \\
\hline \multicolumn{5}{|l|}{ Jarak Posyandu } \\
\hline Sangat Dekat ( $1-10$ meter $)$ & 1 & 4,2 & 5 & 16,1 \\
\hline Dekat (10 - 50 meter) & 7 & 29,2 & 11 & 35,5 \\
\hline Sedang (50 - 100 meter) & 12 & 50,0 & 9 & 29,0 \\
\hline Jauh (> 100 meter) & 4 & 16,7 & 6 & 19,4 \\
\hline \multicolumn{5}{|l|}{ Dukungan Keluarga } \\
\hline Tidak Ada & 15 & 62,5 & 16 & 51,6 \\
\hline Ada & 9 & 37,5 & 15 & 48,4 \\
\hline \multicolumn{5}{|l|}{ Peran Kader Posyandu } \\
\hline Kurang Baik & 1 & 4,2 & 0 & 0 \\
\hline Sudah Baik & 23 & 95,8 & 31 & 100,0 \\
\hline
\end{tabular}

B. Tingkat Partisipasi Ibu dalam Kegiatan Posyandu

Tingkat partisipasi ibu dalam kegiatan posyandu berkisar antara $1-13$ kali kunjungan per tahun, dengan rata-rata 8,84 (SB : 3,00) kali kunjungan per tahun.

Berdasarkan tabel 2, diketahui lebih dari separuh ibu berada pada tingkat 
partisipasi aktif dalam kegiatan posyandu

$(56,4 \%){ }^{8}$

Tabel 2. Distribusi Frekuensi Tingkat Partisipasi Ibu dalam Kegiatan Posyandu (N=55)

\begin{tabular}{|c|c|c|c|}
\hline Tingkat Partisipasi Ibu & & $\mathrm{n}$ & $\%$ \\
\hline Tidak Aktif & & & \\
\hline$<8$ kali kunjungan per tahun & & 24 & 43,6 \\
\hline Aktif & & & \\
\hline$\geq 8$ kali kunjungan per tahun & Total & $\begin{array}{l}31 \\
55\end{array}$ & $\begin{array}{c}56,4 \\
100,0\end{array}$ \\
\hline
\end{tabular}

\section{Tingkat Kecukupan Energi dan Protein} (TKE dan TKP)

TKE anak balita berkisar antara 59,80 $-268,70 \%$ AKG individu, dengan rata-rata $134,01 \%$ (SB : 53,33\%) AKG individu. TKP anak balita berkisar antara 145,20 -
$841,40 \%$ AKG individu, dengan rata-rata $388,00 \%$ (SB : 187,33\%) AKG individu.

Tabel 3 menunjukkan distribusi frekuensi TKE dan TKP anak balita dari ibu dengan tingkat partisipasi posyandu tidak aktif dan aktif.

Tabel 3. Distribusi Frekuensi Tingkat Kecukupan Energi dan Protein ${ }^{13}$

\begin{tabular}{|c|c|c|c|c|c|}
\hline \multirow{2}{*}{$\begin{array}{l}\text { Asupan } \\
\text { Zat Gizi }\end{array}$} & \multirow{2}{*}{$\begin{array}{c}\text { Tingkat Kecukupan } \\
\text { Zat Gizi }\end{array}$} & \multicolumn{2}{|c|}{$\begin{array}{l}\text { Partisipasi Ibu } \\
\text { Tidak Aktif }\end{array}$} & \multicolumn{2}{|c|}{$\begin{array}{c}\text { Partisipasi Ibu } \\
\text { Aktif }\end{array}$} \\
\hline & & $\mathrm{n}$ & $\%$ & $\mathrm{n}$ & $\%$ \\
\hline \multirow{5}{*}{ Energi } & Kurang $(<100 \%$ AKG & 8 & 33,3 & 4 & 12,9 \\
\hline & individu) & 1 & 4,2 & 2 & 6,5 \\
\hline & $\begin{array}{l}\text { Baik (100-105\% AKG } \\
\text { individu) }\end{array}$ & 15 & 62,5 & 25 & 80,6 \\
\hline & Lebih (> 105\% AKG individu) & & & & \\
\hline & Total & 24 & 100,0 & 31 & 100,0 \\
\hline \multirow{5}{*}{ Protein } & Kurang $(<100 \%$ AKG & 0 & 0 & 0 & 0 \\
\hline & individu) & 0 & 0 & 0 & 0 \\
\hline & $\begin{array}{l}\text { Baik (100 - 105\% AKG } \\
\text { individu) }\end{array}$ & 24 & 100,0 & 24 & 100,0 \\
\hline & Lebih (> 105\% AKG individu) & & & & \\
\hline & Total & 24 & 100,0 & 31 & 100,0 \\
\hline
\end{tabular}

\section{Status Gizi}

Status gizi anak balita berdasarkan $\mathrm{BB} / \mathrm{U}$, memiliki skor $\mathrm{Z}$ berkisar antara 3,26-1,17 SD, dengan rata-rata $-1,07$ (SB : 1,05) SD. Berdasarkan BB/TB berkisar antara $-2,70-3,35 \mathrm{SD}$, dengan rata-rata 0,02 (SB : 1,20) SD. Berdasarkan TB/U berkisar antara $-3,84-1,01 \mathrm{SD}$, dengan rata-rata $-1,99$ (SB : 1,06) SD. Berdasarkan IMT/U berkisar antara $-2,66-3,35 \mathrm{SD}$, dengan rata-rata $0,28(\mathrm{SB}: 1,23) \mathrm{SD}$.

Tabel 4 menunjukkan distribusi frekuensi status gizi anak balita berdasarkan $\mathrm{BB} / \mathrm{U}, \mathrm{BB} / \mathrm{TB}, \mathrm{TB} / \mathrm{U}$, dan IMT/U dari ibu dengan tingkat partisipasi posyandu tidak aktif dan aktif.

Tabel 4. Distribusi Frekuensi Status Gizi ${ }^{11}$

\begin{tabular}{clccccc}
\hline \multirow{2}{*}{$\begin{array}{c}\text { Status } \\
\text { Gizi }\end{array}$} & \multicolumn{1}{c}{$\begin{array}{c}\text { Interpretasi Kategori } \\
\text { Status Gizi }\end{array}$} & \multicolumn{2}{c}{$\begin{array}{c}\text { Partisipasi Ibu } \\
\text { Tidak Aktif }\end{array}$} & \multicolumn{2}{c}{$\begin{array}{c}\text { Partisipasi Ibu } \\
\text { Aktif }\end{array}$} \\
\cline { 3 - 7 } & & \multicolumn{2}{c}{ S } & $\%$ & $\mathrm{n}$ & $\%$ \\
\hline \multirow{3}{*}{ BB/U } & Gizi lebih $=>+2$ SD & & 0 & 0 & 0 & 0 \\
& Gizi baik $=\geq-2$ s.d. +2 SD & & 19 & 79,2 & 25 & 80,6 \\
& Gizi kurang = -2 s.d. -3 SD & 4 & 16,7 & 5 & 16,1 \\
\hline
\end{tabular}




\begin{tabular}{|c|c|c|c|c|c|}
\hline \multirow{10}{*}{$\mathrm{BB} / \mathrm{TB}$} & Gizi buruk $=<-3 \mathrm{SD}$ & 1 & 4,2 & 1 & 3,2 \\
\hline & Total & 24 & 100,0 & 31 & 100,0 \\
\hline & Sangat gemuk $=>+3 \mathrm{SD}$ & 0 & 0 & 1 & 3,2 \\
\hline & Gemuk $=>+2$ s.d. +3 SD & 0 & 0 & 0 & 0 \\
\hline & Risiko gemuk $=>+1$ s.d. +2 & 4 & 16,7 & 6 & 19,4 \\
\hline & SD & 20 & 83,3 & 21 & 67,7 \\
\hline & Normal $=\geq-2$ s.d. +1 SD & 0 & 0 & 3 & 9,7 \\
\hline & Kurus $=<-2$ s.d. -3 SD & 0 & 0 & 0 & 0 \\
\hline & Sangat kurus $=<-3 \mathrm{SD}$ & & & & \\
\hline & Total & 24 & 100,0 & 31 & 100,0 \\
\hline \multirow{5}{*}{$\mathrm{TB} / \mathrm{U}$} & Tinggi $=>+2 \mathrm{SD}$ & 0 & 0 & 0 & 0 \\
\hline & Normal $=\geq-2$ s.d. +2 SD & 9 & 37,5 & 19 & 61,3 \\
\hline & Pendek $=<-2$ s.d. -3 SD & 9 & 37,5 & 7 & 22,6 \\
\hline & Sangat pendek $=<-3 \mathrm{SD}$ & 6 & 25,0 & 5 & 16,1 \\
\hline & Total & 24 & 100,0 & 31 & 100,0 \\
\hline \multirow{8}{*}{ IMT/U } & Sangat gemuk $=>+3 \mathrm{SD}$ & 0 & 0 & 1 & 3,2 \\
\hline & Gemuk $=>+2$ s.d. +3 SD & 1 & 4,2 & 2 & 6,5 \\
\hline & Risiko gemuk $=>+1$ s.d. +2 & 6 & 25,0 & 7 & 22,6 \\
\hline & SD & 17 & 70,8 & 19 & 61,3 \\
\hline & Normal $=\geq-2$ s.d. +1 SD & 0 & 0 & 2 & 6,5 \\
\hline & Kurus $=<-2$ s.d. -3 SD & 0 & 0 & 0 & 0 \\
\hline & Sangat kurus $=<-3 \mathrm{SD}$ & & & & \\
\hline & Total & 24 & 100,0 & 31 & 100,0 \\
\hline
\end{tabular}

\section{Analisis Bivariat}

Tabel 5. Analisis Korelasi Bivariat

\begin{tabular}{cccccc}
\hline \multirow{2}{*}{ Variabel Bebas } & \multirow{2}{*}{ Hasil } & \multicolumn{4}{c}{ Variabel Terikat } \\
\cline { 3 - 6 } & & BB/U & BB/TB & TB/U & IMT/U \\
\hline \multirow{2}{*}{ Tingkat } & $\mathrm{r}$ & $\mathbf{0 , 6 5 1}$ & 0,000 & 0,191 & $-0,055$ \\
Partisipasi Ibu & Arah & Positif & Positif & Positif & Negatif \\
dalam Kegiatan & Kekuatan & Kuat & Sangat & Sangat & Sangat \\
Posyandu & $p$ & $\mathbf{0 , 0 3 0}$ & Lemah & Lemah & Lemah \\
& $p$ & 0,998 & 0,163 & 0,689 \\
\hline
\end{tabular}

Berdasarkan tabel 5, diketahui hanya terdapat hubungan tingkat partisipasi ibu dalam kegiatan posyandu dengan status gizi anak balita berdasarkan $\mathrm{BB} / \mathrm{U} \quad(p=0,030 ; \mathrm{r}=0,651)$.

\section{Analisis Korelasi Parsial}

Tabel 6. Analisis Korelasi Parsial setelah dikontrol TKE

\begin{tabular}{ccccccc}
\hline \multirow{2}{*}{$\begin{array}{c}\text { Variabel } \\
\text { Kontrol }\end{array}$} & \multirow{2}{*}{$\begin{array}{c}\text { Variabel } \\
\text { Bebas }\end{array}$} & \multirow{2}{*}{ Hasil } & \multicolumn{4}{c}{ Variabel Terikat } \\
\cline { 4 - 7 } & & & BB/U & BB/TB & TB/U & IMT/U \\
\hline \multirow{3}{*}{ TKE } & Tingkat & r & $\mathbf{0 , 6 3 9}$ & 0,022 & 0,164 & 0,020 \\
& Partisipasi & Arah & Positif & Positif & Positif & Negatif \\
& Ibu dalam & Kekuatan & Kuat & Sangat & Sangat & Sangat \\
& Kegiatan & & Lemah & Lemah & Lemah \\
& Posyandu & $p$ & $\mathbf{0 , 0 4 7}$ & 0,876 & 0,236 & 0,884 \\
\hline
\end{tabular}


Tabel 7. Analisis Korelasi Parsial setelah dikontrol TKP

\begin{tabular}{ccccccc}
\hline \multirow{2}{*}{$\begin{array}{c}\text { Variabel } \\
\text { Kontrol }\end{array}$} & \multirow{2}{*}{$\begin{array}{c}\text { Variabel } \\
\text { Bebas }\end{array}$} & \multirow{2}{*}{ Hasil } & \multicolumn{4}{c}{ Variabel Terikat } \\
\cline { 4 - 6 } & & & SB/U & BB/TB & TB/U & IMT/U \\
\hline \multirow{3}{*}{ TKP } & Tingkat & $\mathrm{R}$ & $\mathbf{0 , 8 2 3}$ & 0,016 & 0,187 & 0,035 \\
& Partisipasi & Arah & Positif & Positif & Positif & Negatif \\
& Ibu dalam & \multirow{2}{*}{ Kekuatan } & Sangat & Sangat & Sangat & Sangat \\
& Kegiatan & Kuat & Lemah & Lemah & Lemah \\
& Posyandu & $P$ & $\mathbf{0 , 0 0 3}$ & 0,911 & 0,176 & 0,800 \\
\hline
\end{tabular}

Berdasarkan tabel 6 dan 7, diketahui hanya terdapat hubungan tingkat partisipasi ibu dalam kegiatan posyandu dengan status gizi anak balita berdasarkan $\mathrm{BB} / \mathrm{U}$ setelah dikontrol TKE $(p=0,047)$ dan TKP $(p=0,003)$. Namun, TKP $(r=0,823)$ memiliki kekuatan korelasi yang lebih kuat dalam mengontrol hubungan kedua variabel daripada TKE $(r=0,639)$.

\section{PEMBAHASAN}

\section{Deskripsi Karakteristik Subjek Penelitian}

Tingkat partisipasi ibu aktif dalam penelitian ini sebesar 56,4\%, menunjukkan belum mencapai target SPM Jawa Tengah tahun 2011 (< 80\%). Rendahnya tingkat partisipasi ibu dalam kegiatan posyandu disebabkan oleh kurangnya kesadaran ibu akan pentingnya posyandu, sebagai akibat dari tidak maksimalnya pokok kegiatan posyandu di meja 4 (penyuluhan gizi). Hal ini didasarkan pada fakta lapang, dimana ibu yang menjadi responden mengungkapkan jarangnya pelaksanaan penyuluhan gizi di posyandu. Keterbatasan jumlah kader menyebabkan penyuluhan gizi hanya dilaksanakan apabila bidan desa hadir saat posyandu diselenggarakan. Saat penyuluhan gizi, seharusnya kader dapat memberikan informasi untuk meningkatkan pengetahuan ibu, sehingga ibu dapat berperilaku sesuai dengan pengetahuannya, yakni bersedia untuk rutin berpartisipasi dalam kegiatan posyandu. Ibu dengan tingkat partisipasi posyandu tidak aktif hanya memiliki pengetahuan baik tentang gizi sebesar $4,2 \%$. Kenyataannya, sebesar $37,5 \%$ ibu dengan pengetahuan gizi kurang dan $58,3 \%$ ibu dengan pengetahuan gizi sedang yang termasuk kategori tidak aktif tetap berkunjung ke posyandu. Penelitian Hartaty (2005) menjelaskan hal ini dapat disebabkan oleh faktor sosial budaya/ kebiasaan orang tua terdahulu, dimana ketika di masa kecil ibu sakit, orang tuanya selalu membawa ibu ke posyandu. ${ }^{14}$

Kegiatan posyandu di Kelurahan Cangkiran sering diselenggarakan pada pagi hari, menyesuaikan jadwal petugas Puskesmas Mijen. Adanya kesibukan ibu bekerja $(16,4 \%)$, baik ibu yang aktif maupun tidak aktif, dan/atau kesibukan lainnya (mengurus rumah dan kesibukan lain diluar rumah selain bekerja), tentu dapat menyebabkan ibu berhalangan hadir saat posyandu diselenggarakan.

Lebih dari separuh ibu aktif, berusia 15 - < 32 tahun $(67,7 \%)$. Kelompok ini termasuk dewasa muda, dimana perhatian mereka terhadap kesehatan biasanya sangat besar dan lebih bersikap moderat, sehingga lebih mudah diberi instruksi untuk berpartisipasi dalam kegiatan posyandu. ${ }^{15}$ Ibu dengan pendidikan SMA/ Sederajat paling banyak aktif dalam kegiatan posyandu $(48,4 \%)$ daripada ibu dengan pendidikan SD/ Sederajat atau SMP/ Sederajat. Hal ini disebabkan semakin tinggi tingkat pendidikan maka semakin mudah seseorang untuk menerima informasi, sehingga pengetahuannya akan semakin baik. ${ }^{3}$ Ibu aktif sebagian besar memiliki penghasilan di atas UMR (80,6\%). Semakin tinggi pendapatan, umumnya suatu keluarga akan mengupayakan agar anggota keluarganya memperoleh pelayanan kesehatan memadai, termasuk pelayanan posyandu bagi anak balita. ${ }^{16}$ Separuh ibu aktif (51,6\%), sudah memiliki motivasi pribadi untuk datang ke posyandu. Hal ini menunjukkan ibu sudah memiliki sikap awareness (kesadaran), interest (merasa tertarik), dan bersedia untuk trial (mencoba) dalam mengadopsi perilaku baru yang positif. ${ }^{14}$

Sebesar 35,5\% ibu aktif menjangkau posyandu dengan jarak dekat sedangkan 50,0\% ibu tidak aktif beralasan menjangkau posyandu dengan jarak sedang. Hal ini terjadi karena semakin dekat jarak tempuh rumah dengan 
tempat penyelenggaraan posyandu maka akan lebih banyak masyarakat yang memanfaatkan posyandu. Peran kader yang dianggap trampil, ramah, dan baik oleh ibu aktif $(100,0 \%)$, diharapkan akan lebih mudah memotivasi ibu untuk tetap rajin berkunjung dan memanfaatkan pelayanan kesehatan di posyandu. ${ }^{17}$

\section{Hubungan Tingkat Partisipasi Ibu dalam Kegiatan Posyandu dengan Status Gizi Anak Balita}

Berdasarkan hasil analisis bivariat, terdapat hubungan tingkat partisipasi ibu dalam kegiatan posyandu dengan status gizi anak balita berdasarkan $\mathrm{BB} / \mathrm{U} \quad(p=$ $0,030)$ tetapi tidak terdapat hubungan apabila dinilai berdasarkan $\mathrm{BB} / \mathrm{TB} \quad(p=$ $0,998), \mathrm{TB} / \mathrm{U}(p=0,163)$, dan IMT/U ( $p=$ $0,689)$. Hasil penelitian ini sesuai dengan penelitian Maulida (2008), Ulfa (2008), dan Bonaventura (2011). ${ }^{18-20}$ Semakin tinggi tingkat partisipasi ibu dalam kegiatan posyandu dapat mempengaruhi status gizi anak balita di Kelurahan Cangkiran karena status gizi anak balita akan terus dipantau oleh kader dan petugas puskesmas melalui KMS yang menggunakan $\mathrm{BB} / \mathrm{U}$ sebagai indikator antropometri pemantauan status gizi, sehingga apabila terdapat gangguan kesehatan, akan lebih cepat diketahui dan ditindaklanjuti.

Tidak ditemukannya hubungan tingkat partisipasi ibu dalam kegiatan posyandu dengan status gizi berdasarkan $\mathrm{BB} / \mathrm{TB}$, bertentangan dengan penelitian Evie (2010). ${ }^{21}$ Malnutrisi berdasarkan BB/TB dan IMT/U yang terjadi dalam penelitian ini yaitu kekurusan, risiko kegemukan, kegemukan, dan sangat gemuk. Masalah tersebut harus segera ditangani, karena masalah kekurusan dan kegemukan pada usia dini dapat berakibat pada rentannya anak balita terhadap berbagai penyakit degeneratif pada usia dewasa (Teori Barker). ${ }^{22}$

Tidak terdapatnya hubungan tingkat partisipasi ibu dalam kegiatan posyandu dengan status gizi, juga ditemukan pada penggunaan TB/U. Hasil penelitian ini bertentangan dengan penelitian Faisal (2010). ${ }^{23}$ Tidak adanya pengaruh langsung kegiatan posyandu terhadap status gizi anak balita berdasarkan BB/TB dan TB/U disebabkan karena di 5 wilayah kerja posyandu Kelurahan Cangkiran jarang dilakukan pengukuran tinggi badan. Jikapun diukur, kader posyandu tidak menginterpretasikan maksud dari pengukuran tersebut kepada ibu. Apabila pemantauan status gizi memfokuskan BB/TB dan TB/U seperti halnya $\mathrm{BB} / \mathrm{U}$, tentu di setiap kunjungan posyandu, ibu akan berusaha agar tinggi badan anak balitanya selalu meningkat. Jarangnya pengukuran tinggi badan di wilayah tersebut dikarenakan keterbatasan jumlah kader dan kurang maksimalnya pembinaan serta pelatihan dari petugas puskesmas kepada kader di tiap wilayah kerja posyandu. Selain itu, adanya kemiskinan, perilaku hidup sehat dan pola asuh yang kurang baik, dan sering menderita penyakit berulang karena higiene dan sanitasi yang kurang baik di masa lalu juga dapat menyebabkan anak balita menjadi pendek. $^{24}$

Langkah untuk menumbuhkan partisipasi masyarakat dalam kegiatan posyandu, terutama ibu, dapat dilakukan melalui metode partisipasi dengan persuasi dan edukasi, yakni partisipasi yang didasari pada kesadaran. Metode ini sukar ditumbuhkan dan akan memakan waktu lama tetapi apabila tercapai hasilnya, masyarakat akan mempunyai rasa memiliki dan rasa memelihara. ${ }^{3}$

Kombinasi BB/TB dan TB/U sebaiknya digunakan untuk anak-anak yang bermukim di negara berpenghasilan rendah (termasuk Indonesia), dimana prevalensi stunting jauh lebih tinggi daripada wasting. ${ }^{25}$ Hasil penelitian ini menunjukkan kejadian underweight, wasting, dan stunting masingmasing sebesar $20,0 \%$, 5,5\%, dan $49,1 \%$, sehingga terbukti prevalensi stunting dalam penelitian ini jauh lebih tinggi daripada wasting.

\section{Hubungan Tingkat Partisipasi Ibu dalam Kegiatan Posyandu dengan Status Gizi Anak Balita setelah dikontrol TKE dan TKP}

Berdasarkan hasil analisis korelasi parsial, terdapat hubungan tingkat partisipasi ibu dalam kegiatan posyandu dengan status gizi anak balita berdasarkan $\mathrm{BB} / \mathrm{U}$ setelah dikontrol TKE $(p=0,047)$ dan TKP $(p=$ $0,003)$. Keseimbangan antara asupan energi dan protein (tepat kuantitas dan kualitas) dengan kebutuhan tubuh sangat mempengaruhi peningkatan status gizi. Hal ini disebabkan penyerapan dan penggunaan zat gizi akan optimal, sebab tidak ada faktor anti 
gizi yang menghalangi. Walaupun demikian, faktor lingkungan seperti tidur, istirahat, aktifitas fisik cukup, dan keadaan emosional yang rileks dan tenang saat makan, juga menentukan keoptimalan proses penyerapan dan penggunaan zat gizi. ${ }^{26}$

Keseluruhan anak balita, baik dari ibu aktif dan tidak aktif, memiliki TKE baik sebesar 5,5\% (3 anak) dan lebih sebesar 72,7\% (40 anak). Bahkan $100,0 \%$ anak balita memiliki TKP lebih (55 anak). Hasil penelitian ini bertentangan dengan Riset Kesehatan Dasar (RISKESDAS) tahun 2007 dan 2010, yang secara konsisten menyebutkan rata-rata asupan energi dan protein balita masih dibawah AKG ${ }^{24,27}$ Tingginya TKE dan TKP dalam penelitian ini disebabkan karena penggunaan AKG individu dalam menentukan TKE dan TKP, pemilihan metode food recall 24 jam untuk menganalisis kandungan zat gizi makanan, dan adanya asupan harian susu formula dari anak balita yang dianggap memberikan energi dan protein terbesar dalam diet. Menurut Jennifer, et al. (2008), perkiraan kandungan zat gizi makro dan mikro dengan food recall lebih tinggi daripada metode penimbangan makanan selama 3 hari. Hal ini disebabkan kesalahan penaksiran ukuran porsi makanan. Namun, wawancara tunggal dengan responden didukung dengan penggunaan alat bantu food model dalam wawancara food recall yang sudah dilakukan dalam penelitian ini, diharapkan dapat meminimalisir kesalahan penaksiran ukuran porsi makanan. ${ }^{28}$

Terdapat 10 anak balita stunting dalam penelitian ini yang mengalami kegemukan $(18,2 \%)$. Apabila dilihat menurut TKE-nya, 8 anak memiliki TKE lebih $(80,0 \%), 1$ anak memiliki TKE baik $(10,0 \%)$, dan 1 anak memiliki TKE kurang (10,0\%). Sedangkan untuk TKP, 10 anak balita memiliki TKP lebih (100,0\%). Terjadinya stunting disebabkan defisiensi protein dan/atau zat gizi mikro selama periode postnatal dan adanya kontribusi faktor genetik dari ibu stunting.

Anak stunting lebih berisiko mengalami kegemukan karena adanya modifikasi metabolik dan kebiasaan untuk membatasi zat gizi selama masih janin. Kondisi ini menyebabkan hambatan pertumbuhan linear yang memudahkan penimbunan lemak di kemudian hari melalui mekanisme gangguan oksidasi lemak, penurunan REE (Resting Energy Expenditure), dan berkurangnya tingkat aktivitas fisik akibat malnutrisi kronis. $^{29}$ Adanya transisi gizi seiring meningkatnya status sosial ekonomi keluarga dan adanya faktor genetik dari ibu obese juga berkontribusi menyebabkan kegemukan pada anak stunting. Transisi gizi diwujudkan dalam peralihan pola diet tradisional (kaya serealia, serat, buah, dan sayur) menjadi diet westernisasi (kaya lemak jenuh dan karbohidrat simpleks) dan perubahan pola sedentary lifestyle yang dikarakteristikkan dengan rendahnya aktivitas fisik. ${ }^{30}$ Kebiasaan diet westernisasi yang banyak ditemukan pada anak balita di Kelurahan Cangkiran, yakni maraknya konsumsi sosis dan mie instan.

\section{SIMPULAN}

Semakin tinggi tingkat partisipasi ibu dalam kegiatan posyandu maka semakin baik pula status gizi anak balita berdasarkan $\mathrm{BB} / \mathrm{U}$. Hal ini turut dipengaruhi oleh TKE dan TKP. Namun, tidak ditemukan hubungan tingkat partisipasi ibu dalam kegiatan posyandu dengan status gizi anak balita berdasarkan BB/TB, TB/U, dan IMT/U, baik sebelum maupun setelah dikontrol TKE dan TKP. Sebagian besar TKE dan TKP anak balita termasuk kategori lebih karena penggunaan AKG individu, pemilihan metode food recall 24 jam, dan tingginya asupan harian susu formula dari anak balita.

\section{DAFTAR PUSTAKA}

1. Kementrian Perencanaan Pembangunan Nasional/ Badan Perencanaan Pembangunan Nasional. Rencana Aksi Nasional Pangan dan Gizi. Laporan Tahunan 2011-2015. Jakarta; 2011 [cited 2012 June 4]. Available from: http://bappenas.go.id/node/165/rencana-aksinasional-pangandangizi-2011-2015/

2. Sulistyorini CI, Pebriyanti S, Proverawati A. Posyandu dan Desa Siaga; Panduan untuk Bidan dan Kader. Yogyakarta: Nuha Medika; 2010.p.3,4,13,20,21,30.

3. Notoatmodjo S. Kesehatan Masyarakat; Ilmu dan Seni. Jakarta: Rineka Cipta; 2007.p.116,143,144,146,147,229.

4. Dinkes Kota Semarang. Rekap SKDN Kota Semarang Tahun 2011. Semarang. In press 2011.

5. Dinkes Kota Semarang. Profil Kesehatan Kota Semarang. Laporan Tahunan 2008. Semarang; 2008 [cited 2012 February 14]. Available from: http://dinkes-

kotasemarang.go.id/download/profil\%202008.pdf

6. Dinkes Kota Semarang. Profil Kesehatan Kota Semarang. Laporan Tahunan 2009. Semarang; 2009 [cited 2012 February 14]. Available from: 
http://dinkes-

kotasemarang.go.id/download/profil_kesehatan_200 9.pdf

7. Dinkes Kota Semarang. Profil Kesehatan Kota Semarang. Laporan Tahunan 2010. Semarang; 2010 [cited 2012 February 14]. Available from: http://dinkeskotasemarang/profil-kesehatan-kotasemarang-2010.pdf

8. Biro Hukum dan Organisasi Sekretaris Jenderal Departemen Kesehatan Republik Indonesia. Kepmenkes RI Nomor: 828/MENKES/SK/IX/2008; Tentang Petunjuk Teknis Standar Pelayanan Minimal Bidang Kesehatan di Kabupaten/Kota. Jakarta; 2008 [cited 2012 February 14]. Available from: $\quad$ http://dinkes.slemankab.go.id/wpcontent/uploads/2011/03/JUKNIS-SPM.pdf

9. Puskesmas Mijen Kota Semarang. Rekap SKDN Kecamatan Mijen Tahun 2011. Semarang. In press 2011.

10. Supariasa IDN, Bakri B, Fajar I. Penilaian Status Gizi. Jakarta: Buku Kedokteran EGC; 2002.p.94,114.

11. Almatsier S, Soetardjo S, Soekatri M. Gizi Seimbang dalam Daur Kehidupan. Jakarta: Gramedia Pustaka Utama; 2011.p.92,103-105.

12. Khomsan A. Teknik Pengukuran Pengetahuan Gizi. Bogor: Institut Pertanian Bogor; 2000.p.30-34.

13. Widajanti. Buku Praktikum Survei Konsumsi Gizi. Semarang: Fakultas Kesehatan Masyarakat, Universitas Diponegoro; 2005.

14. Hartaty. Hubungan Pengetahuan dan Sikap Ibu Balita dengan Kunjungan ke Posyandu di Kelurahan Bara-Baranya Selatan Wilayah Kerja Puskesmas Bara-Bara Makassar [skripsi]. Jurusan Keperawatan, Prodi Makassar [serial online]. 2005 [cited 2012 June 10]. Available from: http://isjd.pdii.lipi.go.id/admin/jurnal/21075966.pdf

15. Triwahyudianingsih I. Hubungan antara Sikap Ibu Balita terhadap Keaktifan dalam Kegiatan Posyandu III Dusun Boto Kabupaten Tulungagung [skripsi]. Program Studi D IV Kebidanan, Fakultas Kedokteran, Universitas Sebelas Maret, Surakarta [serial online]. 2009 [cited 2012 June 10]. Available from:

http://digilib.uns.ac.id/pengguna.php?mn=detail\&d $\mathrm{id}=10594$

16. Lamiati M. Keaktifan Ibu ke Posyandu dan Pola Pertumbuhan Balita di Kelurahan Perdangan I Kabupaten Simalungun Tahun 2008 [skripsi]. Fakultas Kesehatan Masyarakat, Universitas Sumatera Utara, Medan [serial online]. 2009 [cited 2012 February 28]. Available from: http://repository.usu.ac.id/bitstream/123456789/147 18/1/09E01058.pdf

17. Depkes RI, Pokjanal Posyandu. Pedoman Umum Pengelolaan Posyandu. Jakarta; 2006 [cited 2012 February 14]. Available from: http://perpustakaan.depkes.go.id:8180/handle/12345 6789/691
18. Arifiani M. Hubungan Antara Lama Pemberian ASI dan Frekuensi Kehadiran Balita di Posyandu dengan Status Gizi Balita Usia 12-24 Bulan [skripsi]. Program Studi Ilmu Gizi, Fakultas Kedokteran, Universitas Diponegoro, Semarang [serial online]. 2008 [cited 2012 June 9]. Available from: http://eprints.undip.ac.id/25989/1/145MaulidaArifia niG2C206011A.pdf

19. Octaviani U, Juniarti N, Mardiyah A. Hubungan Keaktifan Keluarga dalam Kegiatan Posyandu dengan Status Gizi Balita di Desa Rancaekek Kulon Kecamatan Rancaekek [skripsi]. Fakultas Ilmu Keperawatan, Universitas Padjadjaran, Bandung [serial online]. 2008 [cited 2011 January 14]. Available from: http://pustaka.unpad.ac.id/wpcontent/hubungan_kea ktifan_keluarga.pdf

20. Yogiswara BA. Hubungan antara Tingkat Partisipasi Ibu di Posyandu dengan Status Gizi Balita [skripsi]. Fakultas Kedokteran, Universitas Diponegoro, Semarang [serial online]. 2011 [cited 2012 February 20]. Available from: http://eprints.undip.ac.id/32880/1/Bonaventura.pdf

21. Sopacua E, Widjiartini. Status Gizi dan Morbiditas Balita (0-59 bulan) pada Rumah Tangga yang Mempunyai Balita dan Memanfaatkan Posyandu [Buletin Penelitian Sistem Kesehatan]. Pusat Penelitian dan Pengembangan Sistem dan Kebijakan Kesehatan, Badan Penelitian dan Pengembangan Kesehatan, Kementerian Kesehatan RI, Surabaya [serial online]. 2010; Vol. 13 No.2: 116-122 [cited 2012 June 9]. Available from: http://digilib.ui.ac.id/opac/themes/libri2/abstrakpdf.j sp?id=135385pdf

22. De Boo HA, Harding JE. The Developmental Origins of Adult Disease (Barker) Hypothesis. Australian and New Zealand Journal of Obstetrics and Gynaecology [serial online]. 2006; 46: 4-14 [cited 2012 June 10]. Available from:http://hawaii.edu/publichealth/ecohealth/si/cou rseecohealth/readings/Boo.Harding-2006.pdf

23. Anwar F, Khomsan A, Sukandar D, Riyadi H, Mudjajanto E. High Participation in the Posyandu Nutrition Program Improved Children Nutritional Status. Nutrition Research and Practice (Nutr Res Pract) [serial online]. 2010; 4 (3): 208-214 [cited 2012 June 9]. Available from: http://ncbi.nlm.nih.gov/pmc/articles/PMC2895701/

24. Badan Penelitian dan Pengembangan Kesehatan Departemen Kesehatan RI. Riset Kesehatan Dasar (RISKESDAS). Laporan Nasional 2010. Jakarta; 2010 [cited 2012 June 4]. Available from: http://riskesdas.litbang.depkes.go.id/download/Tabel Riskesdas2010.pdf

25. Gibson R. Chapter 10: Anthropometric Assessment of Body Size. In: Principles of Nutritional Assesment. 2nd ed. Newyork: Oxford University Press. Inc; 2005.p.254-56,337. 
26. Almatsier S. Prinsip Dasar Ilmu Gizi. Jakarta: Gramedia Pustaka Utama; 2002.p.24,105.

27. Badan Penelitian dan Pengembangan Kesehatan Departemen Kesehatan RI. Riset Kesehatan Dasar (RISKESDAS). Laporan Nasional 2007. Jakarta; 2007 [cited 2012 June 4]. Available from: http://archive.k4health.org/system/.../laporanNasiona 1\%20Riskesdas\%202007.pdf

28. Fisher J, Butte N, Mendoza P, Wilson T, Hodges E, Reidy K, et al. Overestimation of Infant and Toddler Energy Intake by 24-h Recall Compared with Weighed Food Records. The American Journal of Clinical Nutrition [serial online]. 2008 [cited 2012 June 8]. Available from: http://ajcn.org/content/88/2/407.full.pdf
29. Mohamed RS, Bernard JY, Ndzana AC, Pasquet P. Is Overweight in Stunted Preschool Children in Cameroon Related to Reductions in Fat Oxidation, Resting Energy Expenditure and Physical Activity?. The PLoS one Journal [serial online]. 2012 [cited 2012 July 14]. Available from: http://plosone.org/.../info\%3Adoi\%2F10.1371

30. McDonald CM, Baylin A, Arsenault JE, Plazas MM, Villamor E. Overweight is More Prevalent than Stunting and is Associated with Socioeconomic Status, Maternal Obesity, and a Snacking Dietary Pattern in School Children from Bogota, Colombia. The American Journal of Clinical Nutrition [serial online]. 2009 [cited 2012 July 14]. Available from: http://ncbi.nlm.nih.gov/pmc/journals/ 